\title{
ATR Kinase Inhibitor M6620
}

National Cancer Institute

\section{Source}

National Cancer Institute. ATR Kinase Inhibitor M6620. NCI Thesaurus. Code C116355.

An inhibitor of ataxia telangiectasia and rad3-related (ATR) kinase, a DNA damage response kinase, with potential antineoplastic activity. Upon administration, ATR kinase inhibitor M6620 selectively binds to and inhibits AT R kinase activity and prevents AT Rmediated signaling in the ATR-checkpoint kinase 1 (Chk1) signaling pathway. This prevents DNA damage checkpoint activation, disrupts DNA damage repair, and induces tumor cell apoptosis. ATR, a serine/threonine protein kinase upregulated in a variety of cancer cell types, plays a key role in DNA repair, cell cycle progression, and survival; it is activated by DNA damage caused during DNA replication-associated stress. 